\title{
Supply Chain Management on Inventory Indonesian Drug Industry
}

\author{
Firdaus*, Roos Kities Andadari, Hari Murti Mahatma Putra, Sri Sulandjari \\ Doctoral Program of Management, Universitas Kristen Satya Wacana, Salatiga, Indonesia
}

\author{
*Corresponding Author \\ Email: Firdaus.fatir37@gmail.com
}

Received:

4 December 2020
Revised:

21 December 2020
Accepted:

31 December 2020
Published:

31 December 2020

\begin{abstract}
The development of the human population in the world, especially Indonesia, to date is approximately 260 million people, making Indonesia in a big challenge where Indonesia must be able to meet the domestic drug supplies needed by the community. The availability of drugs is still an obstacle in the National Health Insurance in Indonesia, this requires the role of the pharmaceutical industry in supporting drug availability by implementing good supply chain management. The focus of this discussion is to look at drug supplies in Indonesia in meeting people's needs and identify factors for production planning, production capacity and raw material procurement for the pharmaceutical industry in supporting the availability of drugs to support the National Health Insurance. This research is a descriptive study by collecting information from various literatures on pharmacy and medicines in Indonesia with a focus on the discussion of production planning, production capacity and raw material procurement and delivery to pharmaceutical companies in supporting drug availability. Because the planning for drug needs used as a basis for drug procurement is inaccurate so that pharmaceutical companies cannot make accurate production plans and the quantity of drugs for the community is inaccurate, time and unavailable at any time, the need for and procurement of materials still depends on imported raw materials from abroad around $95 \%$ with a lead time of 1-3 months so that it has the potential to deplete drug supplies and make the National Health Insurance in Indonesia worse.
\end{abstract}

Keywords: drugs inventory; pharmaceutical industry; production planning; production capacity; procurement of raw material; delivery

\section{INTRODUCTION}

Indonesia has changed its face in the world of health where Indonesia is able to grow to become one of the largest generic drug providers in the Asia Pacific region. By placing a National Health Insurance system in Indonesia, the government through the ministries and health institutions must work harder to meet domestic drug needs. Looking at the existing opportunities In 2016, the Indonesian generic drug market had revenues of more than USD 910 million and it is expected that by the end of 2021, the market will generate revenues of more than USD 1.5 billion (Satibi et al, 2020). Having several domestic players who are active in leading the industry makes 
industrial growth look safe compared to other industries (Chapela et al, 2015). To answer the big challenges in health, it requires strategic steps keeping in mind that Indonesia's population of BPS will reach 271 million by 2020, expanding access to health care creates a landscape of great opportunities for pharmaceutical companies. Of particular relevance will be the market for generic drugs, as the organization responsible for administering the National Health Insurance, the Social Security Administration (BPJS), mandates that 92 percent of drugs on the List of Essential Medicines will be generic drugs. Commenting on the opportunity for the National Health Insurance to meet the needs of the Indonesian pharmaceutical industry (Bank, W., 2009). To realize the national health insurance, a good supply chain management is needed from manufacturing pharmacy. In producing pharmaceutical products from active and inactive raw materials and various packaging materials. The quality of the finished product that is produced only depends on the quality of the input and therefore material management is very important, important activities in pharmaceutical operations and capacity planning are very important in the growth and maturity stage, therefore a large warehouse capacity is required. In fulfilling the demand for the pharmaceutical industry, it is necessary to increase production capacity so that it can carry out production in larger quantities. Production in large quantities can reduce costs compared to producing on a small scale. In this effort, companies also need to consider the ability of product storage facilities or logistics warehousing to be distributed. Therefore facility determination has a large impact on the responsiveness and efficiency of the production chain management. Facility components are location, capacity, production method, and storage method in the warehouse (Friemann et al, 2014). In this case there are several activities that will be carried out by Roy et al. (2013) such as material management activities starting from the selection of line material vendors and packaging materials to the delivery of finished products to their destinations or to consumers. All incoming materials must be immediately sterilized of viruses or bacteria upon receipt or processing, until they are released for use or distribution to consumers.

Material management referred to here is related to planning, procurement, storage and provision of suitable materials with good quality, the right amount in the right place at the right time to coordinate and schedule production activities in an integrated manner for industrial businesses. Most industries buy materials, transport them to factories, turn materials into parts, assemble parts into finished products, sell and transport products to customers. All activities of purchasing materials, the flow of materials, producing them into products, supplying and selling products in the market require various types of materials to manage and control their storage, flow and supply in various places with this, material management can be efficient (Olhager, J., Selldin, E., 2007). Market research and forecasting for both the sale of the company's products and the purchase of various materials are needed to produce the products required at the planning stage. Purchasing, procurement of materials, transportation, storage, inventory control, quality control and inspection of materials and goods supplied at various production centers before production are also managed as routine work. Material handling, packaging, warehouse planning, accounting, scrap, excess and disposal of obsolete materials, finished goods security and maintenance are activities that are managed by the management department. The characteristic of SCM is the successful coordination and integration of all activities related to moving goods from the raw stage to the end user. Activities include systems management, sourcing and procurement, production scheduling, ordering processing, inventory management, transportation, warehousing and customer service (Moharana et al, 2012). 
In Delivery The pharmaceutical supply chain is an example of a rich and multi-stakeholder flow of information. It presents a structured and unstructured, controlled and uncontrolled spread of knowledge, so it may be important for some companies to map it (Pedroso, M.C., Nakano, D., 2009). For this reason, we are interested in analyzing the co-management of the supply chain through the factors of production planning, production capacity and raw material procurement in the pharmaceutical industry to see the availability of drugs in Indonesia. This study tries to find out how these factors such as production planning, production capacity and raw material procurement for the pharmaceutical industry to support drug availability to increase the National Health Insurance. The best organizations with their reverse supply chains are those that explicitly facilitate them with a forward supply chain, creating a closed loop framework (Mridanish Jha, 2015). Supply Chain Management is an important factor that helps improve effective coordination between supply chain partners and productivity (Bala et al, 2014). Micro, Small and Medium Enterprises (MSMEs) around the world have an important role in the socio-economic development of other countries. Their contribution is very significant in parameters such as promoting equitable growth, generating jobs, using local resources wisely, and increasing the country's export income. Despite so many of their contributions, these units generally face problems when competing with foreign companies on the one hand and have not yet integrated into the global supply chain to benefit from being part of the global network that currently exists on the other (Mittal et al, 2017). The success of any organization, whether it is manufacturing or service provision, depends on the supply chain management system. Supply chain management of an organization refers to the supply of finished products or services to end consumers. In the delivery of products to end users, the implementation of the delivery of a coordination framework can be estimated related to the timeliness of delivery and unwavering quality of delivery (Schmidt and Perisic, 2018). Given the importance of the time component, customer delivery execution is often viewed as time-based execution (Christopher, 2016). As a rule, coordination and writing of production networks compete to create a positive effect of chain store integration on customer delivery execution on the grounds of reliable and reliable information sharing. real-time both within and across companies in the inventory network (Murphy and Knemeyer, 2018). Seuring (2013) argues that there are many problems facing production, for example, shortage of spare parts, delivery and quality problems, and increased costs, made with not a danya reconcile an interesting interior and exterior inventory network.

The organization that manufactures products according to the needs and desires of the customer and distributes them to the customer. Customer demand with the supply side of manufacturing organizations, this is only effectively done with the work of a balanced supply chain management organization from the supply side of products or services flowing from the organization meeting the consumer demand side (Prakash Kumar Mahilange, 2016). Supply chain management practice in India stands out from the perceived need for managers, professional professionals and academics to tackle logistics and supply chain practices at the national level. The paper provides insight into the extent to which companies and their supply chains in India have been able to deal with major logistics and supply chain issues, a practice for which they focus or need to focus on health (Joshi, 2018).

Drug management for public drug needs is based on the Decree of the Minister of Health of the Republic of Indonesia Number 1121 of 2008. One of the objectives of drug management is to ensure the availability of drugs in order to support national health insurance. Inefficient drug management can lead to reduced availability of drugs, drug vacancies, and the accumulation of drugs due to poor planning. In a study conducted by Satibi et al, (2020) of 4 pharmaceutical 
companies that won the e-catalog tender, it was confirmed that the four faramsi companies as follows Pharmacy A were the first pharmaceutical industry companies in Indonesia which were founded in 1817 and had 5 (five) production facilities spread across 5 (five) cities in Indonesia, namely Jakarta, Bandung, Semarang, Watudakon and Medan. Pharma B was founded in 1997 and became a young and dynamic pharmaceutical company that produced 75 pharmaceutical products in 2005. Pharma $\mathrm{C}$ was founded in 1966 and has grown to become the leading pharmaceutical company in Indonesia. Through the process of organic growth and business mergers and acquisitions, Pharma has developed into an integrated healthcare solution provider through four business divisions, namely prescription drugs (23\% contribution), health products $(17 \%$ contribution), nutrition (30\% contribution), and distribution and logistics (contribution 30\%). Pharma D was founded in 1974 and is now the operational business of Pharma C. Pharma D is the first Indonesian pharmaceutical company to have three production facilities for Non-Beta Lactams, Penicillins and Cephalosporin Antibiotics. Pharma A dominates the market as a general drug provider with 82 types of drugs seen from the list of public drug providers in the e-Catalog.

Pharmacy B and Pharmacy C supply 33 and 34 types of drugs, while Pharma D is the provider of public medicines with 16 types of drugs. Research by Djoko et al. (2019) confirms that SCM in Indonesia still has many obstacles, for example, delivery is sometimes not ontime resulting in new problems and that occurs both in sending raw materials to warehouses and getting to distribution of products to consumers, this certainly results in a guarantee National health in Indonesia is disrupted and requires a more sophisticated SCM in order to coordinate existing problems from both external and internal parties of the company (Christopher, 2016). Astriani (2018) said in his research that the Pharmacy Installation of the Lahat Regency Health Service in 2018 experienced a drug vacuum. Furthermore, in the storage process, the preparation of drug stocks has not used an alphabetical system and there is no special cabinet for narcotic drugs. Apart from that, the drug storage space was not sufficient enough to accommodate the drug stock, causing an excessive accumulation of drug boxes. And there are still insufficient other facilities and infrastructure such as racks and trolleys and human resources in the drug management process.

This is a new record for the government as well as the authorities so that they can coordinate the provision of medicines for people from cities to remote villages so that there will be no more drug vacancies, Setiawati et al, (2020) in research and analysis conducted in a hospital in Jakarta during the May period. to October with the method of planning, control, ABC method, VEN, safety stock, reorder point, providing information that $\mathrm{ABC}$ analysis based on the investment value of the total drug items group A has a percentage of $69.90 \%$; group B $20.07 \%$ and group C $10.03 \%$. The results of ABC analysis based on the use of group A $69.95 \%$; group B $20.04 \%$ and group C $10.01 \%$. The results of VEN analysis for group V 3.24\% absorb investment $5.15 \%$; Group E 60.10\% absorbed 76.56\% investment and group N 36.66\% absorbed $18.29 \%$ investment. Drug planning analysis based on the ABC and VEN methods has high, medium and low investment value, use value and NIK. Meanwhile, the analysis of drug control based on the Lead Time, Safety Stock and Reorder Point methods ensures the availability of drugs on an ongoing basis, this is considered good because Jakarta is the capital city of the Republic of Indonesia. Health-related policies should be the main focus in the country, because when the people are all healthy, it can be ascertained that the country will move forward, a national health insurance is 
formed, but unfortunately because the Indonesian state is very large, it's no wonder we often hear that people from rural areas don't get medicine.

Monika and Vetty (2018) confirm that about $82 \%$ of the types of drugs in warehouses are rarely used, but 53 of them are drugs that have a high investment value that requires special attention. Drugs that have the 5 (five) biggest investment values but are very rarely used (group $\mathrm{C}$ value of use) are: Albuminar 25\%, Octalbin 25\%, Terfacef injection, Trijec 1 gram and Lanmer injection. The next XYZ RS Formulary must issue 530 types of drugs that are not critical and of no use. The smaller number of drugs that enter the formulary will facilitate the process of controlling and storing supplies in Pekanbaru. In dealing with the availability of drugs, it is necessary to control both internally and towards the drug itself at the central level, hospitals and pharmacies as a connector to the community.

Maruf et al, (2019) in their research said that the research shows that the Shoulder Health Center Pharmacy has implemented most of the internal controls according to COSO (Committee of Sponsoring Organizations). The suggestion from this research is that the Shoulder Health Center Pharmacy should make SOP (Standard Operating Procedures) as an effort to limit employee behavior and as a written rule for the smooth running of drug supply management activities at the pharmacy. Given the important role of drugs for national health insurance, it is not surprising that many studies allude to this, Risqi et al, (2016) said that the analysis of the availability of public drugs with 7 (seven) indicators of drug management which includes drug availability according to need based on the 3 largest diseases is obtained an average of $154.7 \%$, suitability of available drugs with the National Formulary of $93.2 \%$, availability of indicator drugs which have a safe availability level of $87.9 \%$, suitability of drug availability with disease patterns of $114.8 \%$, percentage of damaged drugs in the amount of $0 \%$ and expired drugs of $3.26 \%$ with a value of Rp. 18,054,726-, the time of vacancy for indicator drugs was $1.66 \%$, on time delivery of LPLPO was $98.5 \%$.

Kumalasari and Rochmah (2016) found a drug stockout incidence of generic drugs with an average incidence of 56\% in July-December 2015 at the Surabaya Islamic Hospital. This is because there is no inventory planning and control method that has been implemented yet. The results showed that in Surabaya Islamic Hospital there was no specific method of planning and inventory control that was used. Classification of generic drugs based on the level of usage analysis showed that 28 types of drugs were included in the fast moving category. The results of the 2016 demand forecast will be used to control inventory. The results of the calculation of the MMSL method will obtain the minimum and maximum stock values of drug supplies. The results showed that the value of stock control for generic drugs using the MMSL method was obtained. The minimum and maximum stock values of generic drugs were obtained and the value of the number of orders for each generic drug in the fast moving category was obtained.

\section{METHOD}

This research is a descriptive study by collecting information from various literatures on pharmacy and medicines in Indonesia with a focus on the discussion of production planning, production capacity and raw material procurement and delivery to pharmaceutical companies in supporting drug availability. 


\section{RESULTS AND DISCUSSION Drug Requirement Planning}

Table 1. Drug Requirement Plan Drug Requirement Plan

\begin{tabular}{|c|c|c|c|}
\hline Company & Medicine & $\begin{array}{l}\text { Total of Drug } \\
\text { Requirement Plan }\end{array}$ & $\begin{array}{c}\text { Price } \\
\text { (IDR)/Smalle } \\
\text { t drug unit }\end{array}$ \\
\hline \multirow{3}{*}{ Pharma A } & Vitamin B Complex tablet & 841.428 .190 & 117 \\
\hline & Blood buster tablet & 665.352 .190 & 354 \\
\hline & Ascorbat acid tablet $50 \mathrm{mg}$ & 360.332 .730 & 105 \\
\hline \multirow{3}{*}{ Pharma B } & Parasetamol tablet $500 \mathrm{mg}$ & 1.250 .108 .708 & 53 \\
\hline & $\begin{array}{l}\text { Amoxicilin tablet } 500 \mathrm{mg} \\
\text { Mefenamat acid tablet }\end{array}$ & 1.136 .969 .918 & 233 \\
\hline & $500 \mathrm{mg}$ & 556.585 .769 & 103 \\
\hline \multirow{3}{*}{ Pharma $\mathrm{C}$} & $\begin{array}{l}\text { V-BLOC (Karvedilol tablet } \\
6,25 \mathrm{mg} \text { ) }\end{array}$ & 13.188 .739 & 1.560 \\
\hline & $\begin{array}{l}\text { BRONSOLVAN (Teofilin } \\
\text { tablet } 150 \mathrm{mg} \text { ) }\end{array}$ & 8.339 .800 & 295 \\
\hline & $\begin{array}{l}\text { TAMOFEN (Tamoxcifen } \\
\text { tablet } 1 \mathrm{mg} \text { ) }\end{array}$ & 3.491 .670 & 1.862 \\
\hline \multirow{3}{*}{ Pharma D } & $\begin{array}{l}\text { OSCAL (Kalsitriol soft } \\
\text { capsule } 0,5 \mathrm{mcg})\end{array}$ & 3.298 .720 & 2.850 \\
\hline & $\begin{array}{l}\text { Doxorubisin powder } \\
\text { injection. } 10 \mathrm{mg}\end{array}$ & 978.427 & 44.500 \\
\hline & $\begin{array}{l}\text { Cyclosphosphamide } \\
\text { powder injection } 200 \mathrm{mg}\end{array}$ & 888.173 & 63.690 \\
\hline
\end{tabular}

Based on table 1, the impact of the National Health Insurance will vary depending on the effect on drug pricing, volume, and timing of drug manufacture and distribution. If implemented successfully, it is hoped that the National Health Insurance can focus on basic health services, increase new sales geographies for generic and branded products, and improve the competitive environment in the pharmaceutical market for companies producing generic and branded pharmaceuticals, which will reduce prices.

\section{Capacity Production}

The hope that the establishment of JKN will increase the multifold drug market to meet 240 million Indonesians. This means that citizens must increase the production of drugs, especially generic drugs by the Indonesian pharmaceutical industry. This claim is supported because in the Government Regulation of the Republic of Indonesia Number 15 of 2015 concerning the Master Plan for National Industrial Development 2015-2035, the pharmaceutical industry is included in that section. The decision whether to increase production capacity depends on the individual pharmacy, as there will be possible constraints such as a sudden spike in demand for a particular product. The obstacles they will face are not capacity, but because of production scheduling and availability of raw materials (Dewi, S.L., 2015). As currently, the supply of drugs related to corona 19 is still being questioned by all groups including the public regarding the availability of vaccines, this is because the issue in circulation the vaccines that are distributed can only cover around $1 \%$ of the Indonesian population. 


\section{Procurement of Raw Materials}

Drug procurement in Indonesia is mostly imported from China and India. According to data from the Minister of Health, the Republic of Indonesia, the pharmaceutical sector in Indonesia is growing very rapidly in this perhaps uncertain economic condition. The pharmaceutical industry is currently able to produce about $70 \%$ of the need for medicine, but unfortunately it is very dependent on imported raw materials. About $95-96 \%$ of raw materials for medicines are imported, mainly from China and India. This amount can be minimized if the domestic pharmaceutical industry is able to produce medicinal raw materials independently (KEMENKES 2017). Supplier raw materials are selected based on the Approved Vendor List (AVL), to ensure the quality of raw materials meets standard thresholds. Raw materials received from suppliers will be checked first before being used in the production process to ensure the raw materials are in accordance with pre-ordered quality and quantity. The pharmaceutical industry's ability to meet the demand for drug demand from public health facilities also depends on the preparation auction. To produce drugs, from imported raw materials, winning the auction before the e-catalog takes effect, will guarantee the pharmaceutical industry's commitment as the winning auction (Dwiaji, 2016). Based on the results of interviews conducted with Pharma A, B, C and D, it can be concluded that the raw material procurement factors affect the availability of common drugs in the JKN Era in the pharmaceutical industry because imported raw materials are materials with a long waiting time (1-3 months), resulting in increased possibility of a public drug vacuum.

\section{Delivery}

This research focuses on outgoing customer delivery execution, which is called customer delivery execution. The implementation of the delivery of the coordination framework can be estimated related to the timeliness of delivery and quality of delivery that is unwavering (Schmidt and Perisic, 2018). In relation to the importance of the time component, customer delivery execution is often viewed as time-based execution (Christopher, 2016) regulation, coordination and writing of competing production networks to create a positive effect of merging store networks on customer delivery on the grounds of reliable and real-time information sharing both within and across companies in the inventory network (Murphy and Knemeyer, 2018). Seuring (2013) argues that many of the problems facing production, for example, spare parts shortages, delivery and quality problems, and increased costs, are created in the absence of an attractive reconciliation of interior and output inventory networks.

Service delivery processes are uncommon procedures for describing an overall and coordinated methodology for carrying out explicit types of tasks. This provides the whole product life cycle and can be used as a kind of perspective to run a business of comparable quality (Hanaysha, 2016). "As a commercial business substance, organizations can afford to offer low costs to their consumers, when compared to small pharmaceutical organizations. ". By providing great customer service, organizations can balance the impact of higher tariffs by offering superior customer encounters. Customer retention in 
the pharmaceutical industry (Hanaysha, 2016) can be supported in the following ways: Customer relations, Convenience, Frameworks." successful installment, successful protest technique and after sales service.

\section{CONCLUSION}

The availability of drugs in Indonesia cannot be categorized as good, because from various available literature sources there are still drug vacancies in some areas such as in Lahat district (Astriani, 2018) but in some areas such as Jakarta, Jogjakarta and Pekanbaru, it has started to improve (Satibi et al. ; Djoko et al, 2019; Setiawati et al, 2020; Monika and Vetty, 2018; Risqi et al, 2016) even though in its management it is still difficult to realize people's welfare in receiving health services from the government, National health insurance In this case, it cannot be said that it is completely successful because there is still data that we encounter regarding drug vacancies in certain areas, but this can be tolerated because Indonesia's geographic location is very beautiful, making officers sometimes have difficulty in distributing drugs to the public. For the success of the national health insurance system that has been created by the government, it may be best to carry out strict maintenance for areas that are considered underdeveloped areas, and cooperate with several drug companies or carriers of either pharmacies or other drug stores that already have licenses in order to provide medicines appropriately to the community. Meanwhile, for hospitals, especially health centers as a connector to the community, they must have a technology-based system so that it is easy to control the procurement or availability of any drugs that are a priority that is often needed by the community.

\section{REFERENCES}

Ariati, N., (2017). Drug governance in the era of the national health insurance system. Integr. $J$. Dir. Res. Dev. Corrupt. Erad. Comm. 3, 231-243.

Bank, W., (2009). Indonesia health sectors review. Policy Discuss. Notes 1-10.

Britton, K., Koseki, S., Dutta, A., (2018). Expanding markets while improving health in Indonesia: The private health sector market in the JKN era. Health policy plus, Jakarta.

Chapela, V.A., Premjee, N., Stevenson, B., (2015). Industry Exploration: Indonesia Pharmaceuticals, Global Business Report.

Christopher, M. (2016). Logistics \& supply chain management: Pearson Uk.

Dewi, S.L., (2015). Some critical point of drug policy in social guarantee system. Indones. J. Heal. Policy 04, 2015.

Dwiaji, A., Sarnianto, P., Thabrany, H., Syarifudin, M. (2016). Evaluation of public drug procurement on JKN based on e-catalog data for 2014-2015. Indones. Heal. Econ. J. 1, 45.

Friemann, F., Rippel, M., Schönsleben, P. (2014). Warehouse capacities in the pharmaceutical industry - plan or outsource? Ifip Adv. Inf. Commun. Technol. 438, 427-434. 
Hapela, V.A., Premjee, N., Stevenson, B. (2015). Industry exploration: Indonesia Pharmaceuticals, Global Business Report.

Health, M., (2010). Peraturan Menteri Kesehatan Republik Indonesia Nomor.Hk.02.02/Menkes/068/I/2010 Tentang Kewajiban Menggunakan Obat Generik Di Fasilitas Pelayanan Kesehatan Pemerintah. Indonesia.

Hugos, M. H. (2018). Essentials of supply chain management: John Wiley \& Sons.

Jha, M. (2015). A strategic framework for design and implementation of sustainable reverse supply chain with reference to consumer durables. Asian J. Management; 6(4): Oct. -Dec., 2015 Page 342-346.

Joshi, V. Supply Chain Management - A Pathway For Economic Development of SMEs In India. Asian Journal Of Management. 2018; 9(1):745-751.

Ketikidis, P.H., Kontogeorgis, A., Stalidis, G., Kaggelides, K., (2010). Applying E-Procurement System in the Healthcare: The Epos Paradigm. Int. J. Syst. Sci. 41, 281-299.

Khodakarami, F., \& Chan, Y. E. (2014). Exploring the role of customer relationship management (CRM) systems in customer knowledge creation. Information \& Management, 51(1), 2742.

Kumalasari, A., Rochmah, T.N. (2016). Pengendalian persediaan obat generik dengan metode MMSL (Minimum-Maximum Stock Level) di Unit Farmasi Rumah Sakit Islam Surabaya. Jurnal Manajemen Kesehatan Stikes Yayasan Rs.Dr.Soetomo, Vol.2 No.2 Oktober 2016 : 143-152 49.

Kumar, B.S. G, Karthik, K. P. (2014). A conceptual study on supply chain management at mosquito repellent industry, puducherry. Asian J. Management 5(3): July-September, 2014 Page 341-346

Mahilange, P.K. (2016). Effective supply chain management equilibrates the supply and demand management of an organization. Asian J. Management. 2016; 7(3): 231-235.

Maruf, J.M., Tinangon, J.J., \& Walandouw, S.K. (2019). Analysis of internal development of medicine inventory in public sector organizations in puskesmas Bahu. Jurnal Emba Vol.7 No.3 Juli 2019, Hal. 3099 - 3108. Issn 2303-1174.

Minister of Health of The Republic of Indonesia, (2017). Http://Binfar.Kemkes.Go.Id/Jdih. Peraturan Menteri Kesehatan Republik Indonesia, Indonesia.

Mittal, R.K., Aggarwal, V.S., Rawat, D. (2016). Enhancing competitiveness of msmes in india through their integration in global supply chain: A study of challenges faced by firms in gurgaon auto -component cluster. Asian J. Management; 2017; 8(1):59-67.

Moharana, H.S., Murty, J.S., Senapati, S.K., Khuntia, K., (2012). Coordination, collaboration and integration for supply chain management. J. Intersci. Manag. Rev. 2231-1513.

Murphy, P. R., \& Knemeyer, A. M. (2018). Contemporary Logistics.

Olhager, J., Selldin, E., (2007). Strategic choice of manufacturing planning and control approaches: Analysis of driver and performance. Int. Fed. Inf. Process. 246, 35-42.

Pedroso, M.C., Nakano, D., (2009). Knowledge and information flows in supply chains: A study on pharmaceutical companies. Int. J. Prod. Econ. 122, 376-384. 
Risqi, H., Nugraheni, D.A., Medisa, D. (2016). Analisis ketersediaan obat publik pada era jaminan kesehatan nasional di dinas kesehatan Kabupaten Sleman tahun 2015. Prosiding Rakernas Dan Pertemuan Ilmiah Tahunan Ikatan Apoteker Indonesia 2016 E-Issn : 2541-0474.

Roespinoedji, D., Saadah, N.H., Damopolii, V.L.F., Mohamed, A. (2019). The effect of supply chain management on indonesian pharmaceutical industry. Int. J Sup. Chain. Mgt Vol. 8, No. 2, April 2019.

Roy, M., Sharma, P., Gaikawad, A. (2013). Materials management in pharmaceutical industry- a review. World J. Pharm. Res. 2, 1466-1474.

Satibi, S., Copalcanty, F.A., Tuko, E., \& Sawatiandari, L.G. (2020). Pharmaceutical suply chain management in supporting drugs avaibility in the JKN era in Indonesia. International Journal of Scientific \& Technology Research Volume 9, Issue 04, April 2020 Issn 22778616

Schmidt, E., \& Perisic, F. (2018). Customer Controlled Home Delivery: Google Patents.

Setiawati, E., Purba, A.V., \& Hidayat, W.U. (2020). Analysis of drug planning and control at The Pluit Hospital in 2015. Jurnal Ilmu Kefarmasian Indonesia, April 2020, Hlm. 7-14 Vol. 18, No. 1 Issn 1693-1831, E-Issn 2614-6495.

Seuring, S. (2013). A Review of Modeling Approaches For Sustainable Supply Chain

Shekhar, R. B., \& Devi, P. (2007). Supply chain management practices in Indian process industry. International Journal of Business Research, 7(6), 110-115.

Susanto, M.N., \& Permanasari, V.Y. (2019). The application of abc critical index method in medicine management in the pharmacy installation of xyz Hospital Pekanbaru, Riau 2018 . Jurnal Arsi/Februari 2019.

World Health Organization (2012). Pharmaceutical benefits in insurance program mds-3: managing access to medicines and health technologies, 3rd Ed, Management Sciences For Health. WHO, Geneva. 